\title{
Evaluation of Strength Performance of the Fumigation Treated Wood Affected by the Oak Wilt Disease ${ }^{1}($ SPR
}

\author{
Dabin $\mathrm{SONG}^{2} \cdot$ Keonho KIM $\mathbb{D}^{2, \dagger}$
}

\begin{abstract}
Fumigation treatment is mainly used on dead trees affected by the oak wilt disease to prevent the spread of damage. To verify the possibility of intensive use of the damaged Mongolian Oak wood treated by the fumigation treatment, we performed the compression and bending performance evaluation of the fumigation treated wood. The fumigation was done with Nemasect (Metam-sodium) for about 9 months. The dry longitudinal compressive strength of the fumigation treated oak wilt-diseased wood at the ambient temperature and humidity, and the compressive modulus of elasticity were measured to be $58.87 \mathrm{MPa}$, and $5.66 \mathrm{GPa}$, which were similar to the non-treated wood. The strength performance of mature wood of fumigation treated wood was $16 \%$ higher than that of juvenile wood. The compression fracture of the non-treated oak wood showed various shapes, however, most of the fumigation treated wood showed shear-type fracture shape. The bending strength of the fumigate treated wood was measured to be $157.43 \mathrm{MPa}$, which was $8 \%$ higher than that of the non-treated wood, and the bending modulus of elasticity was measured to be $16.38 \mathrm{GPa}$, which was $16 \%$ lower than that of the non-treated wood. However, it was confirmed that the coefficient of variation for the bending strength performance value of the fumigation treated wood was lower than that of the non-treated wood.
\end{abstract}

Keywords: fumigation treated wood, oak wilt-disease, compressive strength, bending strength, mongolian oak

\section{INTRODUCTION}

Oak woods are Korea's representative hardwood species, and are divided into Galcham oak, Chinese cork oak, Daimyo oak, Sawtooth oak, Mongolian oak, and Jolcham oak (Q. aliena, Q. variabilis, Q. dentata, Q. acutissima, Q. mongolica, Q. serrata). Among the various oak woods, Mongolian oak has a high specific gravity (0.78), is stronger than other hardwoods in terms of strength performance, and has excellent weather resistance, paintability, and adhesion (Bae,
2012; Jeong and Park, 2007). And from the past to the present, it has been used in a variety of ways as wood, such as furniture, architecture, utensils, charcoal, mushroom cultivation, pulp, and veneer. Oak trees account for $24.2 \%$ of the national forests, with the highest share, and it is higher than pine trees (The national atlas of Korea, 2016). The damage caused by oak wilt disease to oak trees, which have the largest vegetation area, is decreasing every year, however, the cumulative number of damaged trees is increasing due to continuous damage. Fig. 1 shows the current status of

${ }^{1}$ Date Received August 3, 2020, Date Accepted October 19, 2020

2 Timber Engineering Division, Forest Products Department, National Institute of Forest Science, 57 Hoegi-ro, Dongdaemun-gu, Seoul 02455, Republic of Korea

† Corresponding author: Keonho KIM (e-mail: keon@korea.kr, ORCID: 0000-0001-6423-164X) 


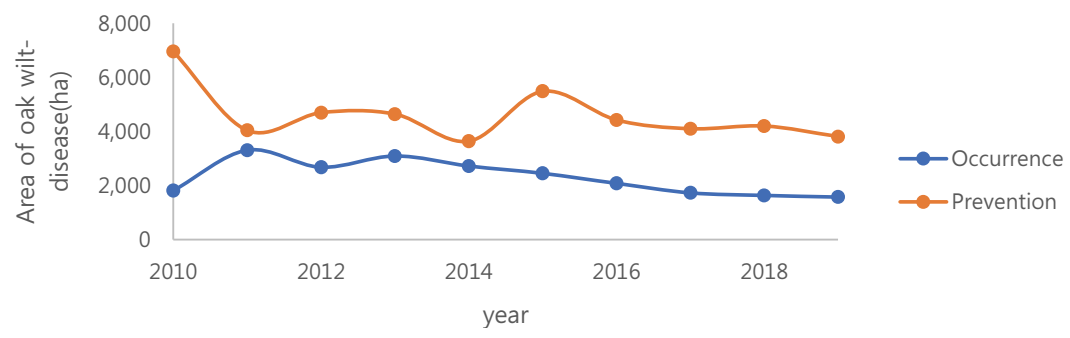

Fig. 1. Occurrence and prevention status of oak wilt-disease by year (KSF, 2019).

outbreak and control of oak wilt disease, taken from the Statistical Yearbook of Forestry (2019). The oak wilt disease is caused by the symbiotic action between the pathogen (Raffaelea quercus-mongolicae) mediated by the vector insect Platypus koryoensis. The first case was confirmed in August 2004 from Gwangju City and Seongnam City, Gyeonggi Province, and is currently being confirmed in 80 cities, counties, and districts nationwide. Oak wilt disease causes rapid death due to the impediment of the water supply in trees (Kim et al., 2009). The damaged woods can be identified by many holes for vector insects in the trunk and thick branches less than $2 \mathrm{~m}$ above the ground, and wood excrement piled up in the branch with intrusion holes. General methods to prevent the spread of damage by oak wilt disease include chemical (precipitation treatment, insecticide injection to the wood), biological (use of natural enemy), and forestry control (thinning). In order to prevent the spread of damage to dead trees caused by oak wilt disease, fumigation treatment after logging, incineration treatment, or insecticide is used to remove vector insects by spraying directly on the wood (Kim et al., 2016). Among them, fumigation treatment after logging is the most used (Suh et al., 2010). The fumigation treatment after logging method is a method of cutting a wood infected with oak wilt disease into $1 \mathrm{~m}$ length wood, which are fumigated with Metam-sodium, sealed in plastic bags, and left for a certain period of time. Metam-sodium is one of the most preferred insecticides because it is effective against vector insects and pathogens, and methyl isocyanate (MIC), which is harmful to the human body, is detected below the standard after the first day or is not detected at all, so it is widely used from the past to the present (Jeong et al., 2015).

Currently, there are no examples for the use of fumigation treated wood except for the method of crushing and incineration of treated wood after fumigation to make biofuel. Also, with the increase of fumigation treatment of the continuously occurring dead trees, the cumulative amount of fumigation treated wood in the mountain is expected to increase. Accordingly, it is necessary to study how to use the fumigation treated wood as a high value-added wood, and the feasibility of using it as a building material was reviewed since the 24 months period of the pine wood nematode diseased pine fumigation does not significantly affect the bending performance (Yun et al., 2012). Therefore, in this study, the strength performance of the fumigation treated oak wood damaged by oak wilt disease was studied to verify the possibility of its strength use as a building material and establish a basic dataset.

\section{MATERIALS and METHODS}

\subsection{Materials}

The target species of oak wilt fumigation-treated wood is Quercus mongolica Fisch. Ex Ledeb, which mainly grows in Asia such as in China and Japan, as well as in Korea, and Fumigation-treated wood (FTW) was fumigated with Nemasect (Metam-sodium) for 


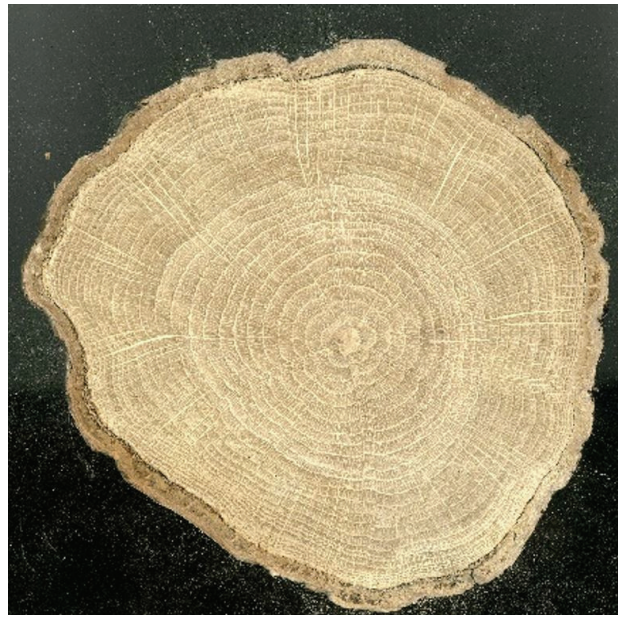

Fig. 2. Photograph of fumigation treated wood of Quercus mongolica Fisch. Ex Ledeb.

approximately 9 months at Forest Environment Research Institute. FTW was used by selecting 5 logs from the chest diameter $(1.2 \mathrm{~m})$. The average length of the wood from the woods of which age of between 10 and 20 years was $98.75 \mathrm{~cm}$ and the average diameter was $16.50 \mathrm{~cm}$, and the latewood rate was $81.4 \%$. The average specific gravity of FTW was 0.74 (Fig. 2).

To compare with FTW, Non-treated wood (NTW) was prepared from the Mongolian oak woods selected and harvested from the Northern National Forest Management Office (Chuncheon-si, Gangwon-do), which were not infected with oak wilt disease. NTW was at least 40 years old or older, with an average length of $100.00 \mathrm{~cm}$ and an average diameter of $29.60 \mathrm{~cm}$. The average latewood proportion of FTW specimens was $78.6 \%$, and the average specific gravity was 0.80 . The strength performance test sample was prepared from the diameter of breast height $(1.2 \mathrm{~m})$, as it was done with FTW.

\subsection{Experiment method}

\subsubsection{The preparation of strength performance test samples}

Bending strength and compressive strength test samples were prepared for strength performance tests of Korean standards. The strength performance of logs is different for the juvenile and mature woods, and the boundary of the annual rings is reported to be about 5 to 20 annual rings in the case of conifers (Green et al., 1999). For the compressive strength test samples, the raw wood was divided into juvenile wood and mature wood as shown in Fig. 3. The size of the test sample was $20 \mathrm{~mm}(\mathrm{~T}) \times 20 \mathrm{~mm}(\mathrm{R}) \times 30 \mathrm{~mm}(\mathrm{~L})$, and 10 test samples were prepared for each part in the longitudinal direction so that the same ring was included in consideration of the number of repetitions (Fig. 3). The bending strength test samples were $20 \mathrm{~mm}$

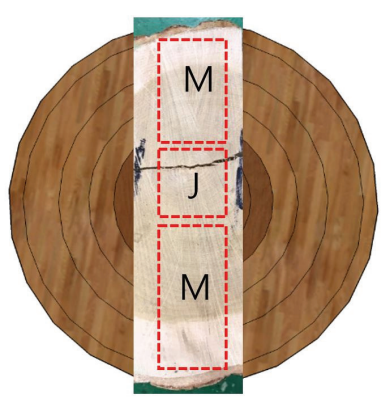

(Cross section)

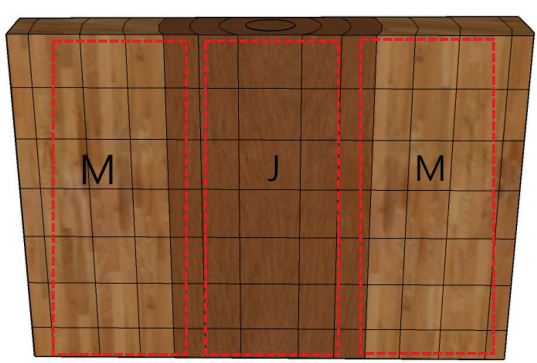

(Tangential section)

Fig. 3. Schematic diagram and photograph by preparation of specimen (J: Juvenile wood, M: Mature wood). 
$(\mathrm{T}) \times 20 \mathrm{~mm}(\mathrm{R}) \times 300 \mathrm{~mm}(\mathrm{~L})$, and considering the diameter, 7 bending strength test samples of FTW, and 40 bending strength test samples of NTW were prepared.

The prepared test sample was stored for at least one week in a constant temperature and humidity room with a temperature of $25^{\circ} \mathrm{C}$ and a relative humidity of $65 \%$ before the test.

\subsubsection{The evaluation of compression performance test}

The moisture content was measured by the 'Method of measuring the moisture content of wood' (KS F 2199:2016). A $20 \mathrm{~mm} \times 20 \mathrm{~mm} \times 30 \mathrm{~mm}$ test sample was prepared, weighed, and dried in a constant temperature dryer at $103 \pm 2^{\circ} \mathrm{C}$ until the constant weight was reached, and the weight was measured, and the average moisture content was measured using the oven-drying method. In order to compare the strength performance according to the annual ring direction, a compressive strength test sample was prepared based on the 'Compression Test Method of Wood' (KS F 2206:2014) focusing on juvenile woods. The compressive strength test sample was tested at a load speed of $0.5 \mathrm{~mm} / \mathrm{min}$ using a universal strength tester (Instron, UK/5585), and then the longitudinal compressive strength $\left(\sigma_{c}\right)$ and the longitudinal compressive modulus of elasticity $\left(E_{c}\right)$ were calculated using equations (1) and (2). The modulus of elasticity was calculated using the amount of deformation within the proportional limit (Fig. 4).

$$
\sigma_{C}=P / A
$$

$\sigma_{C}$ : longitudinal compressive strength (MPa)

P: maximum load

A: Cross-sectional area

$$
E_{C}=\frac{(\Delta P \times l)}{(\Delta l \times A)}
$$

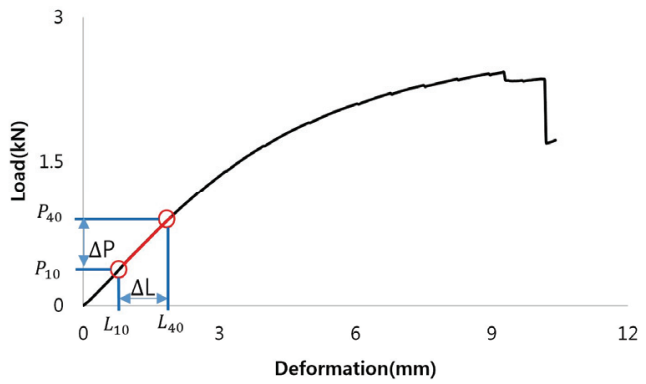

Fig. 4. Load-deformation curve of Control.

$$
\text { Note : } \begin{aligned}
\Delta \mathrm{P}=\mathrm{P}_{40}-\mathrm{P}_{10}, \mathrm{P}_{40}, \mathrm{P}_{10}: 10 \%, 40 \% \text { of } P_{\max } \\
\Delta \mathrm{L}=\mathrm{L}_{40}-\mathrm{L}_{10}, \mathrm{~L}_{40}, \mathrm{~L}_{10}: 10 \% 40 \% \text { of } \\
\text { deformation at } \mathrm{P}_{10}, \mathrm{P}_{40}
\end{aligned}
$$

$E_{C}$ : longitudinal compressive modulus of elasticity $(G P a)$

$\Delta \mathrm{P}$ : Difference of load between upper limit and lower limit in proportional area(kN)

$\Delta \mathrm{l}$ : Transformation corresponding to $\Delta \mathrm{p}(\mathrm{mm})$

l: The length of the test sample (mm)

A: Cross - sectional area $\left(\mathrm{mm}^{2}\right)$

\subsubsection{The evaluation of bending performance test}

The bending strength of the FTW was measured with a universal strength tester (Instron, UK/5585) based on the bending strength test method of wood (KS F 2208:2014). The distance between the points was $280 \mathrm{~mm}$, which is $14 \mathrm{~h}$ of the height of the test sample, and the bending test was conducted with a centralized load, a three-point load method, at a uniform speed so that the test sample is destroyed from 0.5 to 5 minutes. Using equations $(3,4)$, the modulus of elasticity (MOE) and the modulus of rupture (MOR) were calculated. In the MOE equation, $\frac{P_{1}}{\Delta_{1}}$ was obtained in the same manner as in the equation of Fig. 5 .

$$
\text { MOR }=\sigma_{b \max }=\frac{3 P_{\max } l}{2 b h^{2}}
$$

\footnotetext{
MOR: modulus of rupture (MPa)

$P_{\max }:$ maximum load $(N)$

$b:$ width of the test sample $(\mathrm{mm})$

$\mathrm{h}:$ height of the test sample( $\mathrm{mm})$

$1:$ horizontal span of the samples $(\mathrm{mm})$
} 


$$
\mathrm{MOE}=\frac{P_{1} l^{3}}{4 b h^{3} \Delta_{1}}
$$

MOE: modulus of elasticity ( $G P a)$

$P_{1}$ : Difference of load between upper limit and lower limit in proportional limit $(N)$

$\Delta_{1}$ : Deflection in the center of the horizontal span distance at $P_{1}(\mathrm{~mm})$

\section{RESULTS and DISCUSSION}

\subsection{Compressive strength performance evaluation of FTW}

\subsubsection{Compressive strength performance test}

The average moisture content of the FTW was $9.25 \%$ for the juvenile wood and $8.89 \%$ for the mature wood. In the case of NTW, they were $9.75 \%$ and $9.72 \%$, respectively.

The longitudinal compressive strength and compressive modulus of elasticity of FTW and NTW were shown in Table 1. The average longitudinal compressive strength of the FTWwas $61.27 \mathrm{MPa}$ in the mature wood, which was $16 \%$ higher than that of the juvenile wood. The longitudinal compressive strength of NTW and the difference in strength of each part (juvenile wood, mature wood) also showed a similar tendency to that of FTW. The average longitudinal compressive modulus of elasticity was 4.70GPa in the juvenile wood of the FTW, which was $29 \%$ lower than that of the mature wood. In addition, the mature wood of NTW was measured lower than that of the FTW, and the longitudinal compressive modulus of elasticity of the juvenile wood was slightly higher than that of the FTW, but the variation in the value was measured to be large. Contrary to the results of this study, Merela (2016) reported that the strength performance of mature and juvenile woods was measured similarly. Therefore, it is believed that further research is needed to investigate the difference in compression performance of each part of the Mongolian Oak wood.

In the linear regression analysis of longitudinal compressive strength and longitudinal modulus of elasticity of FTW, $R^{2}=0.374$, as shown in Fig. 5, was higher than the correlation coefficient of NTW.

\subsubsection{Compression fracture shape}

The compressive failure mode of the NTW were splitting, shearing, wedge splitting, and brooming or end rolling. Among those, shearing was most often observed $(52.4 \%)$, followed by splitting $(15.0 \%)$, brooming or end-rolling $(6.5 \%)$, wedge splitting $(3.3 \%)$, and others $(22.8 \%)$ (Fig. 6). However, in the main fracture shape of the FTW, shearing compression fracture was 97.4\%. Wangaard (1950) classified the compression fracture shapes and reported that the shearing appeared in the most common fracture shape.

Table 1. Comparison of Compressive Properties of Mature wood and Juvenile wood of Mongolian Oak with the Fumigation Treatment

\begin{tabular}{|c|c|c|c|c|c|c|}
\hline & \multicolumn{3}{|c|}{$\begin{array}{l}\text { Fumigation Treated Woods } \\
\text { (FTW) }\end{array}$} & \multicolumn{3}{|c|}{$\begin{array}{c}\text { Non-Treated Woods } \\
\text { (NTW) }\end{array}$} \\
\hline & Juvenile wood & Mature wood & Ave. & Juvenile wood & Mature wood & Ave. \\
\hline $\begin{array}{c}\text { Compressive } \\
\text { strength } \\
\left(\sigma_{c}, M P a\right) \\
\end{array}$ & $\begin{array}{l}61.27 \\
(0.12)\end{array}$ & $\begin{array}{l}51.41 \\
(0.15)\end{array}$ & $\begin{array}{l}58.87 \\
(0.14)\end{array}$ & $\begin{array}{l}60.13 \\
(0.16)\end{array}$ & $\begin{array}{l}50.36 \\
(0.21)\end{array}$ & $\begin{array}{l}57.80 \\
(0.19)\end{array}$ \\
\hline $\begin{array}{c}\text { Compressive } \\
\text { modulus of } \\
\text { elasticity } \\
\left(E_{\mathrm{C}}, \mathrm{GPa}\right) \\
\end{array}$ & $\begin{array}{c}6.62 \\
(0.06)\end{array}$ & $\begin{array}{c}4.70 \\
(0.08)\end{array}$ & $\begin{array}{c}5.66 \\
(0.18)\end{array}$ & $\begin{array}{c}5.16 \\
(0.07)\end{array}$ & $\begin{array}{c}4.85 \\
(0.21)\end{array}$ & $\begin{array}{l}5.02 \\
(0.15)\end{array}$ \\
\hline
\end{tabular}

*() : Coefficient of Variation 

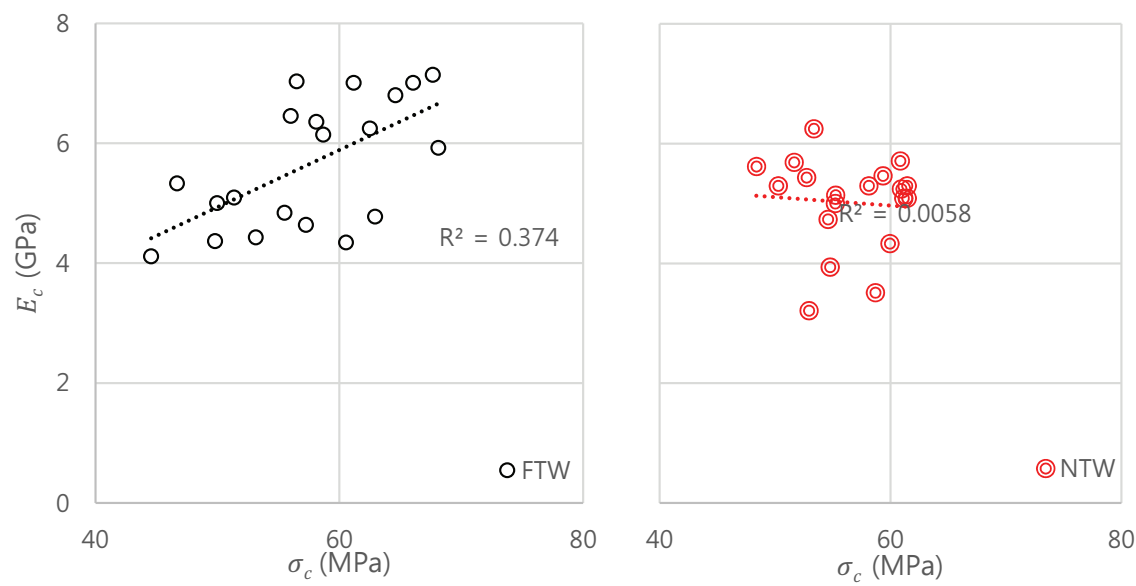

Fig. 5. Relationship between Compressive strength $\left(\sigma_{c}\right)$ and Compressive modulus of elasticity (Ec) of FTW and NTW specimens.
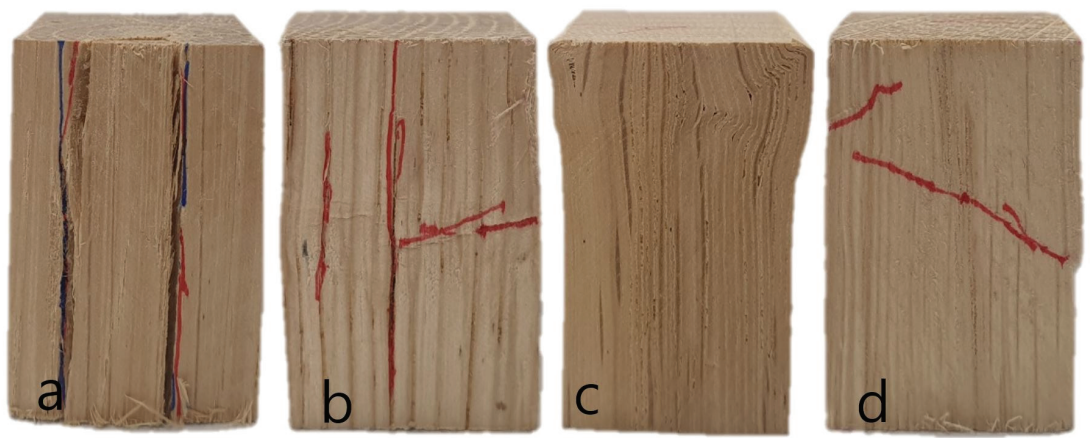

Fig. 6. Failure mode of NTW and FTW compression strength specimen after tests (a: Splitting, b: Wedge splitting, c: Brooming or end rolling, d: Shearing).

As a result of comparing the fracture shape of each part, in the case of juvenile wood $(J)$, splitting fracture occurred in NTW, and shearing failure occurred in FTW. In the mature wood (M), various fracture shapes were shown in NTW, and shearing fracture mostly occurred in the FTW.

\subsection{Bending strength performance test of fumigation treated wood}

In order to find out the effect of fumigation treatment on the bending strength, the bending performance of Mongolian oak wood was compared. The average bending strength of the FTW was measured to be $157.43 \mathrm{MPa}$, which was $8 \%$ greater than that of the NTW. Zhang (1995) studied the specific gravit y and mechanical properties according to the growth rate of distinct wood species and reported that the bending strength of Mongolian oak was $122.2 \mathrm{MPa}$. Although the bending modulus of elasticity of FTW was measured to be $16 \%$ decreased compared to that of NTW, FTW showed 1.09 times bigger bending modulus of elasticity compared to the bending modulus of elasticity of $15.08 \mathrm{GPa}$ suggested by Zhang (1995), so it was thought that fumigation treatment 
Dabin SONG $\cdot$ Keonho KIM

Table 2. The Result of Bending Strength Performance Evaluation Test

\begin{tabular}{|c|c|c|c|c|c|c|}
\hline & \multirow{2}{*}{$\begin{array}{l}\text { Ave. } \\
\mathrm{P}_{\max } \\
(\mathrm{kN})\end{array}$} & \multirow{2}{*}{$\begin{array}{c}\text { Ave. } \\
\text { Stiffness } \\
(\mathrm{N} / \mathrm{mm})\end{array}$} & \multicolumn{2}{|c|}{$\begin{array}{l}\text { Bend Strength } \\
(\mathrm{MPa})\end{array}$} & \multicolumn{2}{|c|}{$\begin{array}{l}\text { Modulus of elasticity } \\
\qquad(\mathrm{GPa})\end{array}$} \\
\hline & & & Exp. & Ref. $^{1)}$ & Exp. & Ref. $^{1)}$ \\
\hline Non-Treated Woods & 2.78 & 567.57 & $\begin{array}{l}145.79 \\
(0.22)\end{array}$ & \multirow{2}{*}{122.2} & $\begin{array}{l}19.47 \\
(0.20)\end{array}$ & \multirow{2}{*}{15.08} \\
\hline $\begin{array}{c}\text { Fumigation Treated } \\
\text { Woods }\end{array}$ & 3.00 & 477.69 & $\begin{array}{l}157.43 \\
(0.09)\end{array}$ & & $\begin{array}{l}16.38 \\
(0.15)\end{array}$ & \\
\hline
\end{tabular}

1) Zhang (1995)

had no significant effect on the bending performance of Mongolian oak (Table 2).

Therefore, it seems that the FTW can be used like the NTW in terms of strength, and the variation coefficient of the FTW in strength performance is lower than that of the NTW, indicating that the fluctuation range of the FTW is less than that of the NTW.

\section{CONCLUSION}

In order to investigate the change in strength performance of oak woods through fumigation treatment of oak wilt disease, the strength performance of FTW and NTW was compared.

1. FTW had a longitudinal compressive strength of $58.87 \mathrm{MPa}$ and a compressive modulus of elasticity of $5.66 \mathrm{GPa}$, which was similar to that of the NTW, and the mature wood showed $16 \%$ higher strength performance than the juvenile wood.

2. In the case of the fracture shape patterns of Mongolian oak by the compressive load, NTW showed a variety of shapes, however, FTW generally showed shearing fracture shape.

3. Through the bending performance evaluation of the fumigation treated Mongolian oak, the average bending strength was $157.43 \mathrm{MPa}$, and the average bending modulus of elasticity was 16.38GPa. It was confirmed that the fumigation treatment method to prevent the spread of damage from oak wilt disease did not affect the strength performance of Mongolian oak.

It is believed that the use of Mongolian oak can be applied to the fumigation treated wood based on the strength property of FTW. However, additional research will be needed to suggest sawing methods and application fields for eco-friendly use.

\section{ACKNOWLEDGMENT}

This study was supported by a research fellowship program through the National Institute of Forest Science (NIFoS), Korea.

\section{REFERENCES}

Bae, S.W., Kim, J.S., Kwon, G.W., Hong, G.N., Kim, I.S., Kim, J.S., Ji, B.Y., Kim, H.S., Cho, M.S., Kim, G.H., Mun, I.S., Son, Y.M., Jeon, C.H., Park, J.H., Lee, H.J., Kim, G.W., Park, B.U., Im, J.H., Kim, S.J. 2012. Commercial Tree Species 2 Oak. Korea Forest Research Institute, Seoul, Korea.

Green, D.W., Winandy, J.E., Kretschmann, D.E. 1999. Mechanical properties of wood. In Wood Handbook: Wood as an Engineering Material. USDA Forest Service, Forest Products Laboratory, Madison, WI, USA.

Jeong, S.H., Park, B.S. 2007. Wood properties of the 
useful tree species grown in Korea. Korea Forest Research Institute, Seoul, Korea.

Jeong, C.S., Nam, Y.U., Choi, W.S., Lee, Y.G. 2015. An analysis on the occurrence of Isorocyanide Methyl (MIC) and Isothiocyanide Methyl (MITC) during fumigating with metam-sodium for control of Pine Wilt Diseases. 2015 Fall Conference of Korean Society of Applied Entomology.

Kim, K.H., Choi, Y.J., Seo, S. T., Shin, H.D. 2009. Raffaelea quercus-mongolicae sp. nov. associated with Platypus koryoensis on oak in Korea. Mycotaxon 110: 189-197.

Kim, S.H., Seo, S.Y., Jang, Y.S., Ryoo, R., Seo, S.T., Ka, K.H. 2016. Study on Sawdust Bag Cultivation of Shiitake (Lentinula edodes), using Oak WiltDiseased Logs. The Korea Journal of Mycology 44(4): 300-306.

Korea Standard. 2016. KS F 2199. Determination of moisture content of wood.

Korea Standard. 2014. KS F 2206. Method of compression test for wood.

Korean Standard. 2014. KS F 2208. Method of bending test for wood.

Korea Forestry Services (KFS). 2019. Statistical
Yearbook of Forestry.

Merela, M., Cufar, K. 2016. Mechanical properties of mature wood versus juvenile wood, in three different oak species. Drvna indstrija 64(4): 323-334.

Ministry of Land, Infrastructure and Transport. 2016. The national atlas of Korea.

Suh, D.H., Son, S.Y., Kim, S.H., Seo, S.T., Kim, K.H., Ko, H.K. 2012. Investigation of fungi in pesticide fumigated oak wilt-diseased logs. The Korea Journal of Mycology 40(4): 288-291.

Wangaard, F.F. 1950. The mechanical properties of wood. John Willey \& Sons, Incorporated, New York.

Yun, S.L., Chong, S.H., Seo, D.J., Won, K.R., Park, H.M., Kim, J.G., Byeon, H.S. 2012. The Effect of Soaking and Fumigation Treatments on Bending Properties and Hardness of Pine Wilt Disease Infected Wood. Journal of the Korean Wood Science and Technology 40(1): 53-59.

Zhang, S.Y. 1995. Effect of growth rate on wood specific gravity and selected mechanical properties in individual species from distinct wood categories. Wood Science and Technology 29(1995): 451-465. 


\title{
APPENDIX
}

\author{
(Korean Version)
}

\section{참나무시들음병 훈증목의 강도 성능 평가}

초록 : 참나무시들음병 고사목으로부터 피해확산을 막기위해 주로 훈증처리 방법을 이용한다. 훈증처리에 따른 신갈나무 피해목의 강도적 활용 가능성을 검증하기 위해 훈증처리목재의 압축성능과 휨성능평가를 수행하였다. 훈증처리목재는 약 9 개월 간 네마섹트(Metam-sodium)로 훈증처리하였다. 참나무시들음병 훈증처리목재의 기건 종압축강도는 $58.87 \mathrm{MPa}$, 압축탄성계수 는 $5.66 \mathrm{GPa}$ 로 측정되었으며 건전목과 비슷한 경향을 보였다. 혼증목의 성숙재부 강도성능은 미성숙재부보다 $16 \%$ 더 높은 강도값을 보였다. 참나무 건전목의 압축파괴형상은 다양한 형상으로 나타나지만 훈증처리목재의 경우 대부분 전단형 파괴형상 을 보였다. 훈증처리목재의 휨강도는 $157.43 \mathrm{MPa}$ 로 건전재보다 $8 \%$ 높게 측정되었고 휨 탄성계수는 $16.38 \mathrm{GPa}$ 로 건전재보다 $16 \%$ 낮게 측정되었다. 그러나 훈증처리목재의 휨강도성능치에 대한 변동계수는 건전목보다 낮은 것을 확인하였다.

\section{1. 서 론}

참나무류는 우리나라 대표적인 활엽수종으로 갈참, 굴참, 떡갈, 상수리, 신갈, 졸참으로 나뉜다. 참나무류 중 신갈나무는 높은 비중 $(0.78)$ 을 가지고 있고 강도적 성능면에서도 다른 활엽수보다 강하며 내후성과 도장성, 접착성이 우수한 장점이 있다 (Bae, 2012; Jeong and Park, 2007). 그리고 과거부터 현재까지 가구, 건축, 기구, 목탄, 버섯재배, 펄프, 화장단판 등 목재이용부분 에서 다양하게 사용되어 왔다. 전국 산림 중 참나무류가 차지하는 비율은 $24.2 \%$ 로 가장 높고 소나무보다 점유율이 높다(The national atlas of Korea, 2016). 식생 면적이 가장 큰 참나무류에 대한 참나무 시들음병의 피해는 매년 감소하는 추세지만 지속적인 피해로 인해 피해목의 누적 본수는 증가하고 있다. Fig. 1은 Statistical Yearbook of Forestry (2019)에서 가져온 참나무 시들음병 발생현황과 방제 현황을 나타낸 것이다. 참나무 시들음병은 매개충인 광릉긴나무좀(Platypus koryoensis)이 매개하는 병원균(Raffaelea quercus-mongolicae)간의 공생 작용에 의해 발병한다. 경기도 광주시, 성남시에서부터 2004년 8월을 시작으로 피해가 확인되었으며 현재는 전국 80 여개의 시군구에서 확인되고 있다. 참나무 시들음병은 목재의 수분공급이 방해되 어 급격히 고사하는 피해가 발생한다(Kim et al., 2009). 피해목의 구분 방법은 지상 $2 \mathrm{~m}$ 이하의 수간부와 굵은 가지에 매개충의 침입공이 많으며 침입공 지제부에 목재배설물이 쌓여 있어 구분할 수 있다. 방제방법은 화학적(침전처리, 살충제 나무주사), 생물적(천적 사용), 임업적 방제(간벌) 등이 있으며 참나무 시들음병으로 인한 고사목의 피해 확산을 막기위해 벌채하여 훈증 처리하거나 소각 처리 또는 살충제를 나무에 직접 분사하여 매개충을 제거하는 방법이 이용된다(Kim et al, 2016). 그 중 벌채훈증처리가 가장 많이 쓰인다(Suh et al., 2010). 벌채훈증처리방법은 참나무 시들음병에 감염된 나무를 $1 \mathrm{~m}$ 길이로 자른 후 메탐소디움(Metam-sodium)으로 훈증하고 비닐로 밀봉하여 일정기간 방치하는 방법이다. 메타소디움은 매개충과 병원균에 게 효과가 있어 가장 선호되는 약제 중 하나이고 훈증 처리시에 나오는 인체에 유해한 이소시안화메틸(Methyl Isocyanate, $\mathrm{MIC}$ )이 1 일차이후에 기준 이하로 검출되거나 미검출되어 과거부터 현재까지 많이 쓰이고 있다(Jeong et al., 2015).

현재 훈증 처리 후 처리 목재를 파쇄와 소각을 하여 바이오연료로 사용하는 방법 외에는 훈증목의 활용에 대한 사례가 전무한 실정이다. 또 지속적으로 발생하는 고사목의 훈증 처리가 증가된다면 산지내 훈증목의 누적량도 증가할 것으로 예상된다. 이에 따라 훈증목을 고부가 가치목재로써 활용할 수 있는 방안의 연구가 필요하며 현재 소나무재선충병 피해 훈증처리목의 24개월 처리기간이 휨성능에 많은 영향을 끼치지 않으므로 건축재로써의 활용가능성이 검토되었다(Yun et al., 2012). 그래서 본 연구에서는 건축재로써 강도적 활용 가능성을 검증하고 기초데이터를 구축하고자 참나무시들음병 피해를 받은 신갈나무 훈증목의 강도성능을 연구하였다.

\section{2. 재료 및 방법}

\section{1. 공시재료}

참나무 시들음병 훈증처리목재의 대상수종은 국내 뿐아니라 중국, 일본 등 아시아에 주로 식생하는 신갈나무(Quercus mongolica Fisch. Ex Ledeb)이며, 훈증처리목재(FTW: Fumigation treated woods)은 산림환경연구소에서 약 9개월간 네마섹트 
(Metam-sodium)로 훈증처리하였다. 훈증목은 흥고직경 $(1.2 \mathrm{~m})$ 위치에서 원목 5 본을 선정하여 사용하였다. 2 영급의 평균 길이 $98.75 \mathrm{~cm}$, 평균 직경 $16.50 \mathrm{~cm}$ 이였고, 만재율은 $81.4 \%$ 이였다. 훈증목의 평균 기건 비중은 0.74 였다(Fig. 2).

훈증목과 비교하기 위한 건전목(NTW: Non-treated woods)은 참나무시들음병에 감염되지않은 북부 국유림 관리소(강원도 춘천시)에서 2 본 선별하여 벌채한 신갈나무를 사용하였다. 건전목은 5 영급 이상으로 평균길이 $100.00 \mathrm{~cm}$, 평균직경 29.60 $\mathrm{cm}$ 이였고 건전목의 만재율은 $78.6 \%$ 이었으며, 평균 기건 비중은 0.80 이였다. 훈증목과 마찬가지로 흥고직경 $(1.2 \mathrm{~m})$ 높이에서 강도성능 시험편을 제작하였다.

\section{2. 실험방법}

\subsection{1. 강도성능시험 시편제작}

강도 성능 실험을 하기 위해 휨강도, 압축강도 시험편을 제작하였다. 원목의 강도성능은 미성숙재와 성숙재에 따라 차이가 발생하며 연륜의 경계는 침엽수의 경우 $5 \sim 20$ 연륜 정도로 보고하고 있다(Green et al., 1999). 압축강도 시험편은 원목을 Fig. 3과 같이 미성숙재부(J), 성숙재부(M)로 나누어 시편을 채취하였다. 시험편의 크기는 $20 \mathrm{~mm}(\mathrm{~T}) \times 20 \mathrm{~mm}(\mathrm{R}) \times 30$ $\mathrm{mm}(\mathrm{L})$ 로 제작하였고 시험편은 반복수를 고려하여 같은 연륜이 포함되도록 길이방향으로 부위별로 10 개를 제작하였다(그림3). 휨강도 시험편은 $20 \mathrm{~mm}(\mathrm{~T}) \times 20 \mathrm{~mm}(\mathrm{R}) \times 300 \mathrm{~mm}(\mathrm{~L})$ 로 직경을 고려하여 훈증목의 휨강도 시험편은 7개, 건전목의 휨강도 시험편은 40 개로 제작하였다.

제작된 시험편은 온도 $25^{\circ} \mathrm{C}$, 상대습도 $65 \%$ 의 항온항습실에서 1 주일 이상 조습시킨 후 실험을 실시하였다.

\subsection{2. 압축성능시험 평가}

함수율은 '목재의 함수율 측정방법' (KS F 2199:2016) 에 의거하였다. $20 \mathrm{~mm} \times 20 \mathrm{~mm} \times 30 \mathrm{~mm}$ 시험편을 제작하여 무게를 측정 후 $103 \pm 2^{\circ} \mathrm{C}$ 항온건조기에서 항량에 도달할때까지 건조 후 무게를 측정하였고 전건법을 이용하여 평균 함수율을 측정하였다. 연륜방향에 따른 강도성능을 비교하기 위하여 미성숙재를 중심으로 '목재의 압축시험방법' (KS F 2206:2014)에 의거하여 압축강도 시험편을 제작하였다. 압축강도 시험편은 만능강도 시험기(Instron, UK/5585)를 사용하여 $0.5 \mathrm{~mm} / \mathrm{min}$ 의 하중속도로 시험한 후 식 (1)과 (2)를 이용하여 종압축강도 $\left(\sigma_{c}\right)$ 및 종압축 탄성계수 $\left(E_{c}\right)$ 를 구하였다. 탄성계수는 비례한도 내에서 변형량을 사용하여 산출하였다(Fig. 4).

$$
\sigma_{C}=P / A
$$

$\sigma_{C}$ : longitudinal compressive strength $(M P a)$

P: maximum load

A: Cross-sectional area

$$
\begin{aligned}
& \qquad E_{C}=\frac{(\Delta P \times l)}{(\Delta l \times A)} \\
& E_{C} \text { : longitudinal compressive modulus of elasticity }(G P a) \\
& \Delta \mathrm{P} \text { : Difference of load between upper limit and lower limit } \\
& \text { in proportional area }(\mathrm{kN}) \\
& \Delta \mathrm{l} \text { : Transformation corresponding to } \Delta \mathrm{p}(\mathrm{mm}) \\
& \text { l: The length of the test sample }(\mathrm{mm}) \\
& \text { A: Cross - sectional area }\left(\mathrm{mm}^{2}\right)
\end{aligned}
$$

\subsection{3. 휨 성능 시험 평가}

훈증목의 휨강도는 목재의 휨강도 시험방법(KS F 2208:2014)에 의거하여 만능강도시험기(Instron, UK/5585)로 측정하였다. 지점 간의 거리는 시험편 높이의 $14 \mathrm{~h}$ 인 $280 \mathrm{~mm}$ 로 하고 시험편이 $0.5 \sim 5$ 분 이내에 파괴되도록 균일한 속도로 3점 하중방식인 중앙 집중 하중으로 휨시험을 실시하였다. 식 $(3,4)$ 를 이용하여 휨탄성계수(MOE, modulus of elasticity)와 휨강도(MOR, modulus of rupture)를 구하였다. 휨탄성계수 식에서 $\frac{P_{1}}{\Delta_{1}}$ 은 Fig. 5 의 식과 동일하게 구하였다. 


$$
\mathrm{MOR}=\sigma_{b \max }=\frac{3 P_{\max } l}{2 b h^{2}}
$$

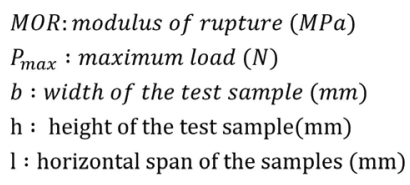

$$
\mathrm{MOE}=\frac{P_{1} l^{3}}{4 b h^{3} \Delta_{1}}
$$

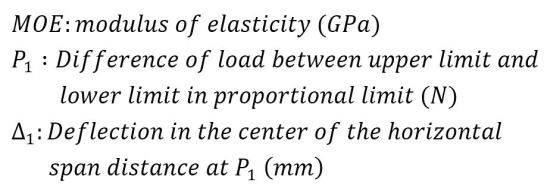

\section{3. 결과 및 고찰}

\section{1. 훈증목의 압축강도 성능 평가}

3.1.1. 압축강도 성능 시험

훈증목의 평균 기건 함수율은 미성숙재부 $9.25 \%$, 성숙재부 $8.89 \%$ 이고 건전목의 미성숙재부, 성숙재부는 평균 기건 함수율이 각각 $9.75 \%, 9.72 \%$ 이다.

Table 1 은 훈증목과 건전목의 종압축강도와 압축탄성계수를 나타낸 것이다. 훈증목의 평균 종압축강도는 성숙재부의 경우 $61.27 \mathrm{MPa}$ 로 미성숙재부보다 $16 \%$ 높게 측정되었다. 건전목의 종압축강도와 부위별 강도차이(미성숙재, 성숙재)도 훈증목과 비슷한 경향을 보였다. 평균 종압축탄성계수는 훈증목의 미성숙재부가 $4.70 \mathrm{GPa}$ 로 성숙재부보다 $29 \%$ 낮았다. 또한 건전목의 성숙재부는 훈증목보다 낮게 측정되었고 미성숙재부의 종압축탄성계수는 건전목이 훈증목보다 약간 높았으나 값에 대한 변이는 크게 측정되었다. 연구결과와는 반대로 Merela (2016)는 신갈나무의 성숙재부와 미성숙재부의 강도성능이 비슷하게 측정되었다 고 보고하였다. 따라서 추후 국내산 신갈나무의 부위별 압축성능의 차이를 규명하기 위한 연구가 필요할 것으로 사료된다.

훈증목의 종압축강도와 종압축탄성계수의 직선 회귀분석에서는 그림 5 과 같이 $R^{2}=0.374$ 로 건전목의 상관계수인 $R^{2}=0.0058$ 보다는 높게 나타났다.

\subsection{2. 압축파괴형상}

건전목의 압축파괴형상은 할렬형(Splitting), 전단형(Shearing), 설할형(Wedge splitting), 끝압연형(Brooming or end rolling) 으로 다양하게 발생하였고 그 중에서 전단형이 $52.4 \%$ 로 가장 많이 관찰되었으며 할렬형( $15.0 \%)$, 끝압연형 $(6.5 \%)$, 설할형 (3.3\%), 기타(22.8\%) 순으로 관찰되었다(Fig. 6). 그러나 훈증목의 주요 파괴형상은 전단형 압축파괴가 $97.4 \%$ 발생하였다. Wangaard (1950)는 압축파괴형상을 구분하고 전단형은 가장 일반적인 파괴 형상에서 나타난다고 보고하였다.

부위별 파괴형상을 비교한 결과 미성숙재부(J)의 경우 건전목은 할렬 파괴, 훈증목은 전단 파괴가 발생했고 성숙재부(M)에서 건전목은 다양한 파괴형상, 훈증목은 전단파괴가 많이 발생하였다.

\section{2. 훈증목의 휨강도 성능 시험}

훈증처리가 휨강도에 미치는 영향을 알아보기 위하여 신갈나무의 휨성능을 비교하였다. 훈증목의 평균 휨강도는 157.43 $\mathrm{MPa}$ 로 측정되었으며 이는 건전목보다 $8 \%$ 크게 나타났다. Zhang (1995)은 고유 수종의 성장률에 따른 비중과 역학적성질을 연구하였으며, 신갈나무의 휨강도는 $122.2 \mathrm{MPa}$ 로 보고하였다. 휨탄성계수는 훈증목이 건전목보다 $16 \%$ 감소한 값이 측정되었 지만 Zhang (1995)이 제시한 휨탄성계수 $15.08 \mathrm{GPa}$ 과 비교하였을 경우 1.09 배 크게 측정되어 훈증처리가 신갈나무의 휨성능에 큰 영향을 미치지 않는 것으로 사료된다(Table 2).

따라서 훈증목이 강도적인 측면에서 건전목과 같이 활용이 가능할 것으로 보이며 강도성능의 훈증목 변동계수가 건전목 
변동계수보다 낮은 것으로 보아 훈증목이 건전목보다 변동폭이 크지 않다는 것을 알 수 있었다.

\section{4. 결 론}

참나무 시들음병 훈증처리를 통한 참나무의 강도성능변화를 알아보기 위하여 훈증목과 건전목의 강도성능을 비교하였다.

1. 훈증목이 종압축강도 $58.87 \mathrm{MPa}$, 압축탄성계수 $5.66 \mathrm{GPa}$ 로 건전목과 유사한 강도성능을 보였으며 미성숙재부보다 성숙재 부가 $16 \%$ 더 높은 강도성능을 보였다.

2. 압축하중에 의한 신갈나무의 파괴형상은 건전목의 경우 다양한 양상을 보였으나, 훈증목은 대부분 전단형 파괴형상을 보였다.

3. 훈증처리된 신갈나무의 휨성능평가를 통해 평균 휨강도는 $157.43 \mathrm{MPa}$, 평균 휨탄성계수는 $16.38 \mathrm{GPa}$ 로 측정되었으며 참나무 시들음병 피해확산을 방지하기 위한 훈증처리방법이 신갈나무의 강도성능에 영향을 미치지 않음을 확인할 수 있었다.

국내산 신갈나무 훈증목의 강도적 기초데이터 제시로 기존 건전목의 활용방안이 훈증목에 적용 가능할 것으로 사료된다. 다만 안정적이고 효율적인 이용을 위해 제재방법 및 친환경적인 이용을 위한 활용분야가 제시될 수 있도록 추가적인 연구가 필요할 것이다. 